\title{
The Gonadotropin-Releasing Hormone Cell-Specific Element Is Required for Normal Puberty and Estrous Cyclicity
}

\author{
Horacio J. Novaira, ${ }^{1}$ Melissa Yates, ${ }^{2}$ Daniel Diaczok, ${ }^{1}$ Helen Kim, ${ }^{3}$ Andrew Wolfe, ${ }^{1}$ and Sally Radovick ${ }^{1}$ \\ ${ }^{1}$ Department of Pediatrics, Division of Endocrinology, and ${ }^{2}$ Department of Gynecology and Obstetrics, Division of Reproductive Endocrinology and \\ Infertility, Johns Hopkins University School of Medicine, Baltimore, Maryland 21287, and 32Department of Obstetrics/Gynecology, University of Chicago \\ Medical Center, Chicago, Illinois 60637
}

Appropriate tissue-specific gene expression of gonadotropin-releasing hormone (GnRH) is critical for pubertal development and maintenance of reproductive competence. In these studies, a common element in the mouse GnRH (mGnRH) promoter, between -2806 and $-2078 \mathrm{bp}$, is shown to mediate differential regulation of hypothalamic and ovarian mGnRH expression. To further characterize this region, we generated a knock-out mouse $\left(\mathrm{GREKO}^{-1-}\right)$ with a deletion of the $\mathrm{mGnRH}$ promoter fragment between -2806 and $-2078 \mathrm{bp}$. GnRH mRNA expression in the brain of GREKO $^{-1-}$ was less than the expression in wild-type mice; however, immunohistochemical analysis revealed no difference between the numbers of GnRH neurons among groups. GnRH mRNA expression in the ovary was fivefold higher in GREKO ${ }^{-1-}$. The immunohistochemical staining for GnRH in the ovary increased in surface epithelial and granulosa cells and also in the corpora lutea of GREKO ${ }^{-1-}$ mice. The reproductive phenotype revealed that the mean day of vaginal opening was delayed, and additionally, there was a significant decrease in the length of proestrus and diestrus-metestrus phases of the estrous cycle, resulting in a shortened estrous cycle in GREKO ${ }^{-1-}$ mice. This work supports the hypothesis that the region of the GnRH promoter contained between -2806 and -2078 bp acts as a cell-specific enhancer in the GnRH neuron and as a repressor in the ovary. Deletion of this region in vivo implicates the $\mathrm{GnRH}$ promoter in mediating pubertal development and periodic reproductive cycling, and forms the foundation to define the nuclear proteins important for puberty and estrous cycling in mammals.

\section{Introduction}

Appropriate tissue-specific expression of gonadotropin-releasing hormone $(\mathrm{GnRH})$ is critical for establishing and maintaining reproductive competence. The significance of the extra-hypothalamic expression of $\mathrm{GnRH}$, or what factors in the hypothalamus and/or extra-hypothalamic tissues direct the differential expression of the GnRH gene, remains unclear.

To investigate the molecular mechanisms that regulate expression of the GnRH gene; mouse-derived immortalized GnRH-secreting neuronal cell lines GT1-7 (Mellon et al., 1990) and GN11 cells (Radovick et al., 1991) have been used for in vitro studies. Transient transfection studies using the rat GnRH ( $\mathrm{rGnRH}$ ) gene promoter identified a $173 \mathrm{bp}$ proximal promoter region (Eraly and Mellon, 1995) and a 300 bp enhancer region located $1.8 \mathrm{~kb}$ upstream from the transcription start site that conferred cell-specific expression (Whyte et al., 1995). Despite

Received Oct. 14, 2010; revised Dec. 8, 2010; accepted Dec. 30, 2010.

This research was supported by National Institute of Child Health \& Human Development (NICHD)/National Institutes of Health (NIH) through cooperative agreement [Grant U54 HD 933067 (The Baltimore-Chicago Center for Reproductive Research)] as part of the Specialized Cooperative Centers Program in Reproduction and Infertility Research (SCCPIR) and Grant R01 as NIH Grant HD 370246. The University of Virginia Center for Research in Reproduction Ligand Assay and Analysis Core was supported by the Eunice Kennedy Shriver NICHD/NIH (SCCPIR) (U54HD28934). We thank Dr. Fredric Wondisford, Dr. Sara DiVall, and Dr. Sheng Wu for the critical support of this work, and Katie Brothers for technical assistance.

The authors declare no competing financial interests.

Correspondence should be addressed to Dr. Horacio J. Novaira, 600 North Wolfe Street, Baltimore, MD 21287. E-mail: hnovair1@jhmi.edu.

DOI:10.1523/JNEUROSCI.5419-10.2011

Copyright $\odot 2011$ the authors $\quad 0270-6474 / 11 / 313336-08 \$ 15.00 / 0$ the insight gained from in vitro studies, cell culture is unable to answer questions regarding whether the promoter of GnRH has a role in the normal physiologic events associated with reproduction, including puberty, estrous cyclicity, and fertility.

In vivo, transgenic mice containing different $\mathrm{GnRH}$ promoter deletion constructs fused to reporter genes have been developed to study the tissue-specific expression and regulation of the GnRH gene. In our previous study, using the luciferase (LUC) reporter gene, we found that the proximal $-1005 \mathrm{bp}$ of the mouse GnRH ( $\mathrm{mGnRH}$ ) promoter contains the critical elements for appropriate neuronal and ovarian expression of $\mathrm{mGnRH}$ (Kim et al., 2002). Furthermore, studies in mice bearing either $-3446 /+23$ or $-2078 /+23$ bp of the $\mathrm{mGnRH}$ promoter fused to the LUC reporter defined a critical enhancer region for the in vivo expression of hypothalamic mGnRH (Kim et al., 2002). Interestingly, ovarian LUC expression was found at high levels in the transgenic mice bearing the $-2078 /+23$ bp fragment, but not in the $-3446 /+23$ bp mice, suggesting that an ovarian GnRH repressor element (OGRE) is located in the distal region of the $\mathrm{mGnRH}$ promoter between -3446 and -2078 bp (Kim et al., 2002).

In this work, to further characterize the $\mathrm{mGnRH}$ promoter, we have constructed an additional transgenic mouse bearing a $-2806 /+23$ bp fragment fused to the LUC reporter gene. This model demonstrates that critical hypothalamic enhancer sequences and ovarian repressor elements for the in vivo expression of $\mathrm{mGnRH}$ are located between -2806 and -2078 bp on the $\mathrm{mGnRH}$ promoter. In addition, a line of knock-out mice bearing 
a deletion of the mGnRH promoter between -2806 and -2078 bp (GREKO mice) have been generated to identify the cisregulatory element of the $\mathrm{mGnRH}$ promoter. This work supports the hypothesis that this region of the GnRH promoter, referred to as the GnRH regulatory element (GRE) contains the hypothalamic GnRH enhancer element (HGEE) and the OGRE. Most importantly, this work for the first time demonstrates that the GRE of the GnRH promoter mediates the timing of pubertal onset and normal estrous cycling, and forms the foundation to define the proteins important for puberty and estrous cycling in mammals mediated by the GRE.

\section{Materials and Methods}

Generation of -2806/+23 bp mGnRH promoter-luciferase mice. Transgenic animals were constructed by the University of Chicago Transgenic Facility by pronuclear injection. Briefly, a DNA construct containing the region from -2806 to $+23 \mathrm{bp}$ of the $\mathrm{mGnRH}$ promoter fused to the LUC reporter gene was used to generate the $-2806 \mathrm{mGnRH}$-LUC transgenic mice. A GnRH promoter-LUC construct containing $-3446-+23$ bp of the $\mathrm{mGnRH}$ promoter fused to $\mathrm{pSV0aL} \Delta 5^{\prime} \mathrm{LUC}$ was kindly provided by Dr. Donald B. DeFranco (University of Pittsburgh, Pittsburgh, PA). Restriction enzyme digestion with BamHI and BglII was performed to remove the sequences between -3446 and -2078 bp of the $\mathrm{mGnRH}$ promoter, generating a linearized $-2078 /+23$ LUC construct. An $\sim 800$ bp fragment of the mGnRH promoter was generated by digestion of $-3446 /+23$ LUC with BglII. The $-2806 /+23$ bp mGnRH-LUC construct was generated by ligating the $\sim 800 \mathrm{bp}$ BglII fragment into the linearized $-2078 /+23$ bp mGnRH LUC construct. Orientation and appropriate ligation was verified by DNA sequencing analysis. Fertilized mouse oocytes from CD-1 mice were injected with the purified linear $-2806 /+23$ mGnRH-LUC DNA fragment. The resulting embryos were transferred into pseudo-pregnant foster mothers. A ${ }^{32} \mathrm{P}$-labeled $1.2 \mathrm{~kb}$ probe for luciferase was used to detect transgenic animals that incorporated the luciferase transgene (Kim et al., 2002). Five different -2806 mGnRH-LUC transgenic mouse lines were obtained.

Assay of $m G n R H-L U C$ transgene. Luciferase expression may be observed wherever GnRH would be expressed. LUC assays of tissue panels from reporter mice were performed as previously described (Kim et al., 2007). Briefly, from adult mice, the hypothalamus was dissected in a single fragment consisting of tissue from $1 \mathrm{~mm}$ caudal to the mammillary bodies to a point just anterior of the optic chiasm, $1 \mathrm{~mm}$ laterally beyond the lateral aspect of the median eminence, and $3 \mathrm{~mm}$ dorsally. The olfactory tissue was dissected to include both olfactory bulbs and the tissue rostral to the hypothalamic section. Small representative sections were taken from the remaining tissues. In the case of the gonads, entire gonads were used due to their small size. Relative light units (RLU) were normalized for tissue size by correcting for protein content. Protein assays were done using Bio-Rad reagent and bovine serum albumin standards.

Generation of the $m G n R H$ promoter knockout between -2806 and $-2078 \mathrm{bp}$. We have used a self-excision procedure that takes advantage of a testes-specific promoter to drive expression of the cAMP response element (Cre) recombinase (Bunting et al., 1999). Briefly, the intragenic promoter of the murine angiotensin-converting enzyme tACE (tumor necrosis- $\alpha$ angiotensin-converting enzyme) (shown to initiate transcription only during spermatogenesis) (Langford et al., 1991) directs expression of Cre; tACE-Cre is linked to the selectable marker gene $\mathrm{Neo}^{r}$, and the two genes $t A C E-C r e / N e o^{r}$ are flanked with loxP sites. This cassette, referred to as ACN, was freed from the vector by digestion with BamHI and ligated into the 3446 LUC vector that had the $-2806 /-2078$ bp fragment excised by BglII digestion. This vector was linearized and used to target into mouse embryonic stem (ES) cells by Primogenix.

Animals. All experimentation was performed in accordance with the Animal Care and Ethics Committees of The University of Chicago and The Johns Hopkins Medical Institutes. All of the mice used in the experiments had mixed B57Bl/6 genetic backgrounds and were maintained under $12 \mathrm{~h}$ light/dark lighting conditions (lights on at 8:00 A.M.) with food and water available ad libitum. Genotyping was undertaken as detailed previously. Prepubertal female mice were examined every day for vaginal opening, and once this had occurred vaginal smears were taken each day until the first estrous smear was encountered.

Quantitative reverse transcribed-PCR. Two micrograms of RNA was reverse transcribed (RT) using the iScript cDNA kit (Bio-Rad). Real-time quantitative PCR was performed in duplicate using SyberGreen MasterMix (Bio-Rad) and the ICycler quantitative PCR machine (Bio-Rad). $18 \mathrm{~S}$ RNA was used as an internal control for cDNA input. The quantitative RT-PCR primer sequences are available on request. PCR conditions were optimized to generate $>95 \%$ PCR efficiency, and only those reactions with between 95 and 105\% efficiency were included in subsequent analyses. Relative differences in cDNA concentration between baseline and experimental conditions were then calculated using the comparative threshold cycle $\left(C_{\mathrm{t}}\right)$ method (Bustin et al., 2005).

Estrous cycle assessment. All animals were housed according to their genotype. Vaginal smears were collected daily at 10:00 A.M. over a period of $12 \mathrm{~d}$ in 2-3-month-old mice and were examined as stained preparations with Diff-Quick stain kit (IMEB) to determine the estrous cycle. The stage of estrous cycle was determined as described by Nelson et al. (1982). The frequencies of the estrous cycles and the proportion of time spent in the different phases included in the estrous cycle were compared between the two groups.

Hypothalamus and ovarian immunocytochemistry. Female mice in diestrus phase were anesthetized with an intraperitoneal injection of 90 $\mathrm{mg} / \mathrm{kg}$ ketamine and $7.5 \mathrm{mg} / \mathrm{kg}$ xylazine. Mice were transcardially perfused with $4 \%$ paraformaldehyde, and brains were analyzed as described previously (Wolfe et al., 2008). Frozen adult brains were cut coronally using a Microm HM 550 (Microm International) in $40 \mu \mathrm{m}$ coronal sections from the median eminence to the accessory olfactory bulbs. After quenching the endogenous peroxidase, slices were blocked with $2 \%$ normal goat serum (Vector Laboratories). Adult brain sections were then incubated with anti-GnRH antibody (Affinity BioReagents). Sections were washed and incubated with biotinylated goat anti-rabbit IgG antibody (Vector Laboratories) and treated for at least $1 \mathrm{~h}$ with avidin-biotinhorseradish peroxidase (Vector Laboratories). Sections were again washed and stained using 3,3'-diaminobenzidine tetrahydrochloride with nickel salts (Vector Laboratories). GnRH-immunoreactive neurons were counted on a Primo Star microscope (Carl Zeiss MicroImaging). Additionally, the ovaries were also removed and after being paraffinembedded the ovaries were then completely sectioned. The deparaffin/ rehydration process was done and immunostaining was performed as noted above. The preabsorption of the primary antibody was performed to confirm the GnRH-specific immunoreactivity staining. Sections of ovaries in diestrus phase were also stained with hematoxylin and eosin $(\mathrm{H} \& \mathrm{E})$ and examined for morphological parameters according to the literature (Spanel-Borowski et al., 2001). Corpora lutea were counted in ovarian sections by comparing the section with preceding and following sections.

Fertility testing. The fertility of the knock-out GREKO ${ }^{-1-}$ female mice was examined by pairing homozygous adult female mice with wild-type (WT) males for a period of 8 months. Female WT littermates of GREKO mice were paired with WT mice as controls. The date of birth and number of pups was recorded for each pair. Mean numbers of litters and pup numbers over this period were determined for each genotype.

Hormonal determinations. To establish hormone levels over the course of the estrous cycle, adult female mice were anesthetized with isofluorane and nightly blood samples were obtained from the facial vein. Samples were obtained for a period of $10 \mathrm{~d}$. Serums were stored at $-80^{\circ} \mathrm{C}$ until the assays were performed. Luteinizing hormone (LH) and folliclestimulating hormone (FSH) were measured using a Milliplex MAP immunoassay (Rat Pituitary panel; Millipore) in the Luminex 200. Analysis was performed using the XPonent 3.0 software program with Logistic $5 \mathrm{D}$ weighted analyses. The limit of detection for the assay for LH/FSH was $0.08 \mathrm{ng} / \mathrm{ml}$. Further details of the analysis are described by Singh et al. (2009). 17 $\beta$-Estradiol $\left(\mathrm{E}_{2}\right)$ was measured with an enzyme immunoassay kit (Cayman Chemical) according to the manufacturer's directions. The limit of detection for this assay was $6 \mathrm{pg} / \mathrm{ml}$. Progesterone was measured using a radioimmunoassay performed by University of Virginia Core Ligand and Assay Laboratory. The limit of detection for this assay was $0.1 \mathrm{ng} / \mathrm{ml}$. 
Statistical analysis. Statistical significance was assessed by one-way ANOVA followed by the Newman-Keuls multiple-comparison post hoc tests when three or more different groups were analyzed. We used an unpaired Student's $t$ test when two groups were compared. All results are expressed as mean \pm SEM, and $p \leq 0.05$ was assigned as significant using the GraphPad Prism 4 software.

\section{Results}

$-2806 \mathrm{bp}$ of the $\mathrm{mGnRH}$ promoter mediates differential regulation of hypothalamic and ovarian $\mathrm{GnRH}$ expression The anatomic pattern of LUC activity in tissue homogenates from five different lines of the $-2806 \mathrm{mGnRH}$-LUC transgenic mice detected high levels of LUC in the hypothalamus and olfactory bulbs. In addition, low levels of LUC activity were detected in the cortex and, minimally, in the ovary. LUC was not detected in other tissues (Fig. 1A). This is a reversal from the anatomic pattern of LUC expression from the eight different lines of the $-2078 \mathrm{mGnRH}$-LUC mice previously reported in Kim et. al. (2002) and reanalyzed for comparison. In the $-2078 \mathrm{mGnRH}$-LUC mice, LUC expression was detected in the hypothalamus and olfactory lobes, but at lower levels than were seen in $-2806 \mathrm{mGnRH}-$ LUC mice. LUC expression was found at very high levels in the ovaries of these transgenic mice, and LUC activity was not detected in other non-neural tissues (Fig. $1 B)$. These findings suggest that DNA sequences contained in the distal region between -2806 and -2078 bp are sufficient to differentially direct hypothalamic and ovarian GnRH expression.

\section{Target deletion of the fragment between -2806 and -2078 bp of mouse GnRH gene}

The Cre-loxP strategy was used to target deletion of the fragment between -2806 and $-2078 \mathrm{bp}$ of the mGnRH gene. To obtain the deletion of this fragment, the tACE-Cre/Neo was introduced via homologous recombination in ES cells (Fig. $2 A, B)$. Three clones containing the appropriate chromosomal recombinant were identified from 288 ES cell clones by PCR using A and B primers, and Southern blot using probe 1 is shown in Figure 2, $A$, $B$, and $D$. Three of the recombinant ES cell lines were used to generate 16 male chimeric mice by injection into blastocyst-stage mouse embryos by the Johns Hopkins Transgenic Core. Chimeras bearing the loxP left after the selfexcision (Fig. 2C) were determined by coat color. Six progeny were bred with C57BL/ 6 female mice, and tails from the F1 progeny were genotyped by PCR using $\mathrm{C}$ and $\mathrm{D}$ primers (Fig. $2 C, E$ ) and Southern blot using probe 1 (Fig. 2C,E) to detect mice heterozygous for WT and loxP alleles.

\section{Hypothalamic and ovarian GnRH mRNA expression in GREKO $^{-1-}$ female mice}

GnRH mRNA expression was evaluated by quantitative RT-PCR in the brain and ovaries of female $\mathrm{GREKO}^{-/-}$mice during the diestrus and proestrus phases of the estrous cycle. During di-

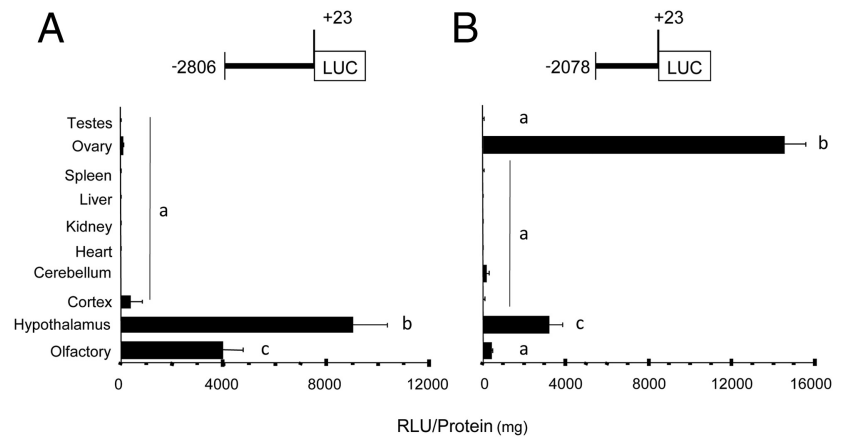

Figure 1. LUC expression in GnRH-LUC reporter mice. The anatomic pattern of LUC expression measured as RLU is a reflection of GnRH promoter activity. $\boldsymbol{A},-2806 \mathrm{mGnRH}-\mathrm{LUC}$ mice. $\boldsymbol{B}$ $-2078 \mathrm{mGnRH}-$ LUC mice. Graphed as means \pm SE of RLU. There is no statistical difference between groups with the same letters $(n=5-10, p \leq 0.05)$.
A

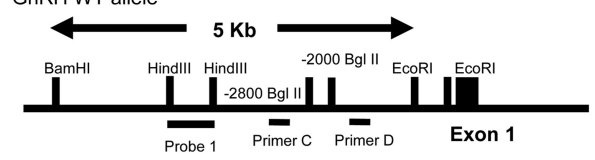

GREKO -2806/-2078 targeting construct
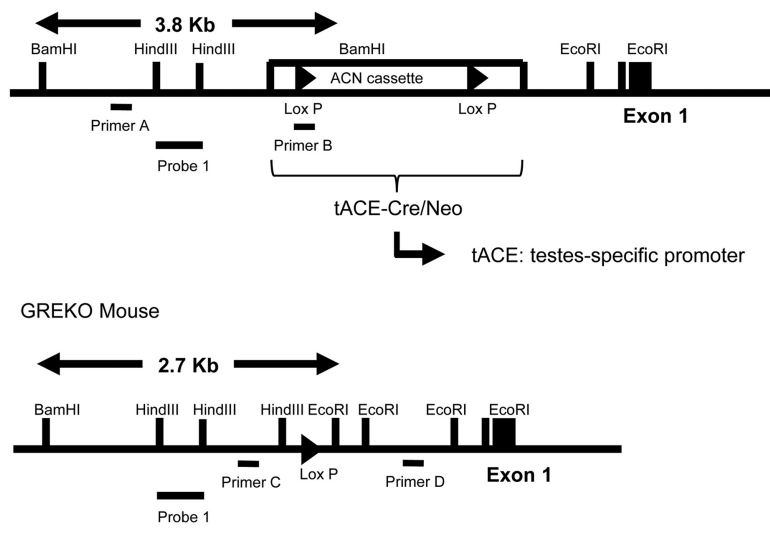

PCR

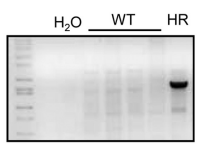

Southern Blot

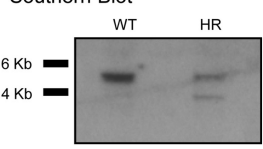

E
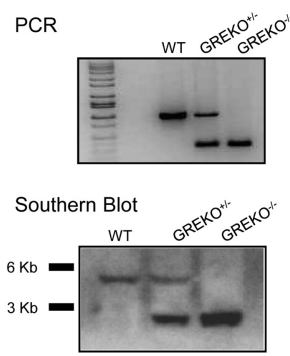

Figure 2. Target deletion of the fragment between -2806 and $-2078 \mathrm{bp}$ of mouse GnRH gene using Cre-loxP strategy. $\boldsymbol{A}$, Schematic map of GnRH WT allele. $\boldsymbol{B}, \boldsymbol{D}$, Homologous recombination (HR) of the targeting vector in ES cells was confirmed by PCR using primer set $A$ and $B$ followed by Southern blot analysis. In Southern blot, genomic DNA was digested with BamHI/EcoRI and detected with a probe 1. $C, E$, Genotyping of GREKO mice was performed using the primer set $C$ and $D$ detecting in $1 \%$ agarose gel a band of $300 \mathrm{bp}$ in the knock-out allele and a band of $900 \mathrm{bp}$ in the WT allele. Southern blot analysis was performed digesting the DNA with BamHI/EcoRI and detected a band of $2.7 \mathrm{~Kb}$ in the $\mathrm{KO}$ allele and a band of $5 \mathrm{~kb}$ in the WT allele with the probe 1 .

estrus, GnRH mRNA expression in the brain of the $\mathrm{GREKO}^{-1-}$ mouse was $52 \%$ less than that found in the WT mice (Fig. $3 A$ ). During the proestrus phase, the GnRH mRNA expression in the brain of GREKO ${ }^{-1-}$ was $65 \%$ less than that found in WT mice (Fig. 3A). In contrast, GnRH mRNA expression in the $\mathrm{GREKO}^{-1-}$ ovaries was fivefold higher when compared with WT ovaries during the diestrus phase (Fig. $3 A$ ). Furthermore, GnRH mRNA expression in the ovaries of $\mathrm{GREKO}^{-1-}$ mice in proestrus remained consistently increased. These data clearly demonstrate an increased ovarian/hypothalamic ratio for GnRH mRNA expression in GREKO ${ }^{-1-}$ mice. Hypothalamic and testicular GnRH mRNA expression was also evaluated in $\mathrm{GREKO}^{-1-}$ male mice. GnRH mRNA expression in the brain of the GREKO ${ }^{-1-}$ male mouse was $65 \%$ less than that found in the WT male mice. 

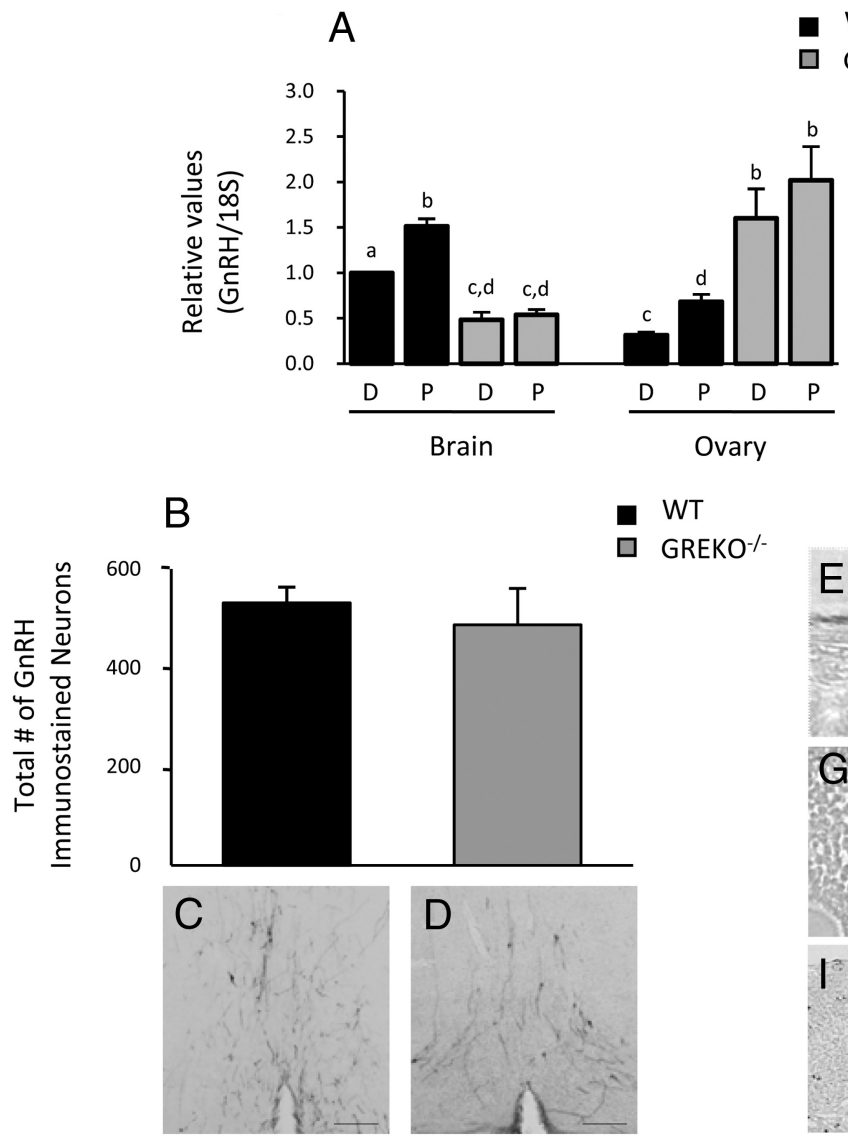

- WT GREKO $\%$

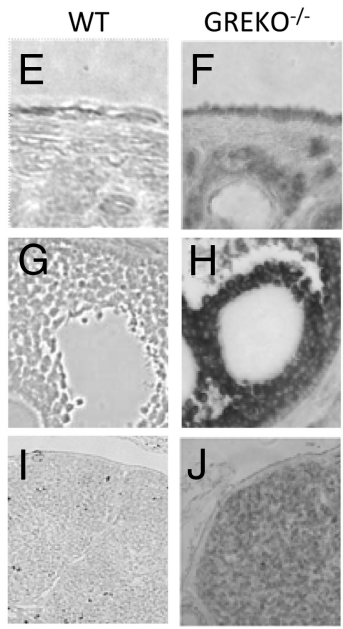

Figure 3. Hypothalamic and ovary GnRH expression in GREKO ${ }^{-1-}$ mice. $\boldsymbol{A}, \mathrm{GnRH}$ mRNA expression at diestrus (D) and proestrus (P) phases. GREKO ${ }^{-1-}$ mice present lower GnRH mRNA levels in brain and higher GnRH mRNA expression in ovary when compared with WT group. Graphed as means \pm SE of relative mRNA levels compared to brains of WT group. There is no statistical difference between groups with the same letters $(n=4-8, p \leq 0.05)$. $\boldsymbol{B}$, Peroxidase immunohistochemistry of GnRH-1 revealed normal number of GnRH-expressing neurons in the hypothalamus of GREKO ${ }^{-1-}$ female mice. $C, D$, Coronal brain sections showing GnRH immunoreactivity in the rPOA. Scale bar, $100 \mu \mathrm{m}$. Ovarian immunostaining for GnRH was robustly higher in the knock-out mice. $\boldsymbol{E}-\boldsymbol{J}, \mathbf{G n R H}$ staining was detected in surface epithelial cells $(\boldsymbol{E}, \boldsymbol{F})$, granulosa cells $(\boldsymbol{G}, \boldsymbol{H})$, and corpora lutea $(\boldsymbol{I}, \boldsymbol{J})(n=5)$. higher in the knock-out mice when compared with ovaries of WT mice in the same phase of the estrous cycle. GnRH staining was detected in surface epithelial cells (Fig. $3 E, F$ ), the granulosa cells (Fig. $3 G, H$ ) and corpora lutea (Fig. $3 I, J$ ) of the GREKO ${ }^{-I-}$ model. The preabsorption of the primary antibody resulted in a complete absence of the respective immunoreactivity.

\section{Pubertal onset and first delivery are} delayed in GREKO ${ }^{-/-}$female mice $\mathrm{GREKO}^{-1-}$ mice produced their first litter $6 \mathrm{~d}$ later (postnatal d $57 \pm 0.44$ ) (Fig. 4C) than the WT mice (postnatal d $51 \pm$ 0.51) (Fig. 4C). For that reason, we examined whether $\mathrm{GREKO}^{-/-}$mice experienced a normal onset of puberty. Interestingly, vaginal opening was significantly delayed by $\sim 6 \mathrm{~d}$ in $\mathrm{GREKO}^{-1-}$ mice (postnatal d $33 \pm 0.62$ ) (Fig. $4 A$ ) when compared with the control WT mice (postnatal d $27 \pm 0.24$ ) (Fig. $4 A$ ). Consequently, the first day of estrus was delayed in $\mathrm{GREKO}^{-1-}$ female mice (postnatal d $35 \pm 0.40$ ) (Fig. $4 B$ ) when compared with WT mice (postnatal d $30 \pm$ 0.28 ) (Fig. $4 B$ ), although it occurred $\sim 2-3 \mathrm{~d}$ after vaginal opening with no differences detected between genotypes. Additionally, WT littermates and $\mathrm{GREKO}^{-1-}$ mice were weighed weekly from day 21 of life until 8 weeks of age, and there were no differences noted between the weights of the WT and $\mathrm{GREKO}^{-1-}$ mice.
Testicular GnRH mRNA expression was not observed in either the $\mathrm{GREKO}^{-1-}$ or WT mice.

\section{Normal number of hypothalamic GnRH-expressing neurons in $\mathrm{GREKO}^{-1-}$ mice}

We examined GnRH neuron number and distribution in adult $\mathrm{GREKO}^{-/-}$mice. Immunohistochemical analysis for $\mathrm{GnRH}$ of brain sections from the WT and GREKO ${ }^{-1-}$ mice, visualized with $\mathrm{DAB} / \mathrm{Ni}^{2+}$, revealed the typical inverted $\mathrm{Y}$ distribution of GnRH cell bodies located within the medial septum (MS), rostral preoptic area (rPOA), and anterior hypothalamic nuclei of both the adult $\mathrm{GREKO}^{-1-}$ and WT mice (Fig. 3C,D). Cell counts in coronal sections extending from the MS through to the anterior hypothalamus estimated that the total $\mathrm{GnRH}$ neuron population in this region was $532 \pm 32$ in WT mice and $487 \pm 74$ in $\mathrm{GREKO}^{-1-}$ mice (Fig. $3 B)$. Thus, GREKO ${ }^{-1-}$ mice exhibited normal GnRH neuron cell numbers in the organum vasculosum of the lamina terminalis.

\section{Staining of ovarian GnRH-expressing cells is higher in female} GREKO $^{-/-}$mice

Immunohistochemistry was performed using a specific $\mathrm{GnRH}$ antibody to further evaluate the previous finding that the expression of GnRH is significantly greater in the ovaries of GREKO ${ }^{-/-}$ than in the WT mice. Immunostaining for GnRH was robustly

\section{Adult GREKO ${ }^{-1-}$ female mice exhibit normal fertility}

The fertility of $\mathrm{GREKO}^{-/-}$female mice was assessed by pairing with WT adult males for a period of 8 months. The frequency, number, and size of litters were observed. WT littermates had litters regularly, with an interval of between 20 and $25 \mathrm{~d}$. GREKO $^{-1-}$ females exhibited a quite irregular delivery time with an interval of between 18 and $42 \mathrm{~d}$ with similar numbers of litters when compared with WT mice (Fig. 4D). Overall, both WT and $\mathrm{GREKO}^{-l-}$ mice produced nine litters in the 8 month period. The size of the litters is shown by the average number of pups per delivery. Both WT and GREKO ${ }^{-1-}$ mice had an average number of eight pups per delivery (Fig. $4 E$ ).

\section{GREKO $^{-1-}$ female mice have shortened estrous cycles}

Estrous cyclicity examined by daily vaginal smear showed that $\mathrm{GREKO}^{-1-}$ female mice exhibited a shorter proestrus phase $(0.87 \pm 0.13 \mathrm{~d})$ (Fig. $5 B)$ and shorter metestrus-diestrus phase $(1.91 \pm 0.21 \mathrm{~d})$ (Fig. $5 B)$ when compared with the proestrus (1.82 \pm $0.13 \mathrm{~d}$ ) (Fig. $5 B)$ and the metestrus-diestrus $(3.33 \pm 0.53 \mathrm{~d}$ ) (Fig. $5 B)$ phases of WT mice, respectively. There was no difference in the mean duration of the estrus phase in WT and GREKO ${ }^{-1-}$ mice. Thus, the mean duration of one estrous cycle was significantly shorter in the GREKO $^{-1-}$ females $(4.6 \pm 0.16 \mathrm{~d})$ (Fig. $\left.5 B\right)$ 
than in WT females $(6.6 \pm 0.46 \mathrm{~d})$ (Fig. 5B). Consequently, $\mathrm{GREKO}^{-1-}$ mice presented an increased estrous cycle frequency over a period of $12 \mathrm{~d}$ (Fig. $5 A, B$, Table 1 ).

\section{Higher serum LH levels during the proestrus surge in GREKO $^{-1-}$ females}

Serum LH and FSH levels during the estrous cycle were examined. The average, nonsurge serum LH values in $\mathrm{GREKO}^{-1-}$ mice were not different when compared with WT females (Fig. $5 C$ ). In the estrus phase, $\mathrm{GREKO}^{-1-} \mathrm{LH}$ values averaged $0.22 \pm$ $0.05 \mathrm{ng} / \mathrm{ml}$ compared with $0.18 \pm 0.06 \mathrm{ng} / \mathrm{ml}$ in WT mice (Fig. $5 C)$. In the metestrus-diestrus phase, $\mathrm{LH}$ values in $\mathrm{GREKO}^{-1-}$ mice were $0.29 \pm 0.04$ versus $0.24 \pm 0.06 \mathrm{ng} / \mathrm{ml}$ in WT mice (Fig. 5C). However, the LH surge (8:00 P.M. LH levels in the proestrus phase) was $39.7 \pm 4.95 \mathrm{ng} / \mathrm{ml}$ in $\mathrm{GREKO}^{-1-}$ mice and $27.37 \pm$ $3.39 \mathrm{ng} / \mathrm{ml}$ in WT mice (Fig. $5 C$ ). Unlike serum LH values, there was no statistical difference in the serum FSH levels between WT and GREKO ${ }^{-1-}$ mice during each phase of the estrous cycle (Fig. 5D). GREKO $^{-1-}$ mice had an average FSH level of $42.42 \pm 5.29$ $\mathrm{ng} / \mathrm{ml}$ in the estrus phase, and WT mice had an average FSH level of $43.70 \pm 7.18 \mathrm{ng} / \mathrm{ml}$ (Fig. 5D). In the proestrus phase, the FSH level in $\mathrm{GREKO}^{-1-}$ mice was $33.05 \pm 2.49 \mathrm{ng} / \mathrm{ml}$ compared with $33.21 \pm 3.47 \mathrm{ng} / \mathrm{ml}$ in WT mice (Fig. $5 D$ ). In addition, in the metestrus-diestrus phase the GREKO ${ }^{-1-}$ FSH value was $26.21 \pm$ 2.62 versus $20.95 \pm 1.98 \mathrm{ng} / \mathrm{ml}$ in WT mice (Fig. $5 D$ ).

\section{No changes in the number of corpora lutea in $\mathrm{GREKO}^{-/-}$ovaries}

H\&E-stained sections of ovaries were examined in the diestrus phase (Fig. 6A,B). The sections show follicles in different stages of development and the presence of multiple corpora lutea. However, ovarian sections from $\mathrm{GREKO}^{-1-}$ mice displayed, in general, less organization than the WT ovaries and an increase in interstitial space. Additionally, GREKO ${ }^{-1-}$ ovaries presented the same variety of different follicle types and the same average number of corpora lutea when compared with WT ovaries (Fig. $6 A-C$ ).
A

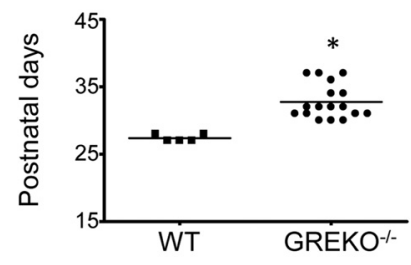

B
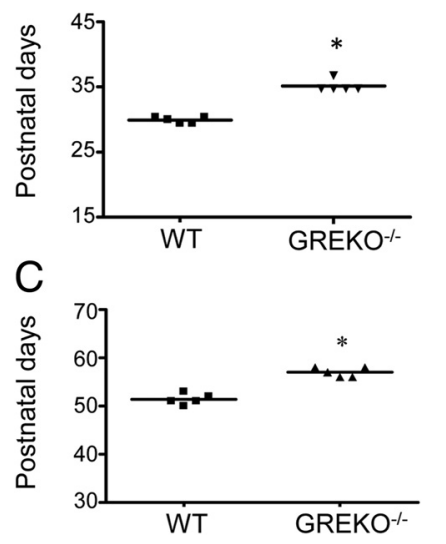

D

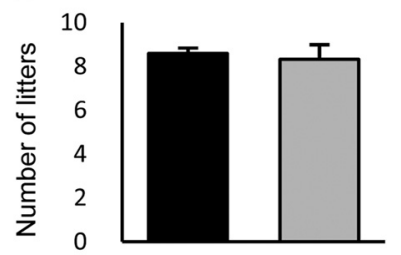

E

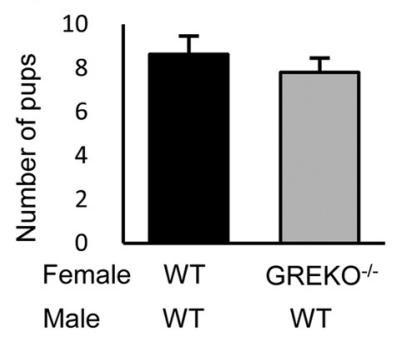

Figure 4. Delayed puberty onset and first delivery in GREKO ${ }^{-1-}$ mice. Mice were examined for the day of vaginal opening and the day of first estrus by vaginal cytology. $\boldsymbol{A}, \boldsymbol{B}$, Graphic representation of the means \pm SE of the day of vaginal opening $(\boldsymbol{A})$ and first estrus $(\boldsymbol{B})$. C, Schematic representation of first delivery of WT and GREKO ${ }^{-/-}$female mice after introduction of a WT male mouse (beginning of mating = day 21 after the day of birth; $n=4-17)$. ${ }^{*} p \leq 0.05$. The fertility study represents 8 months of mating. $\boldsymbol{D}$, Mean numbers of litters for each mating pair. $\boldsymbol{E}$, Mean number of pups born per litter for the different genotypes $(n=6)$.

\section{Higher serum $E_{2}$ and progesterone levels during proestrus in $\mathrm{GREKO}^{-/-}$ females}

Serum $\mathrm{E}_{2}$ and progesterone levels were examined. The average serum $E_{2}$ and progesterone values in GREKO ${ }^{-I-}$ mice were higher when compared with WT females (Fig. $6 D, E$ ). In the proestrus phase, GREKO $^{-1-} \mathrm{E}_{2}$ values averaged $62.85 \pm$ $17.36 \mathrm{pg} / \mathrm{ml}$ compared with $16.69 \pm 1.92$ $\mathrm{pg} / \mathrm{ml}$ in WT mice (Fig. 6D). In the same phase, progesterone values in $\mathrm{GREKO}^{-1-}$ mice were $45.62 \pm 4.1$ versus $27.6 \pm 6.86$ $\mathrm{ng} / \mathrm{ml}$ in WT mice (Fig. 6E).

\section{Discussion}

Using a unique mouse model, these studies provide evidence that the region between -2806 and -2078 bp of the $\mathrm{mGnRH}$ gene acts as a hypothalamic enhancer element and conversely as an ovarian repressor element. Female mice bearing a deletion of this enhancer element with less GnRH mRNA expression in the brain, but normal numbers of GnRH neurons, exhibit normal fertility
A
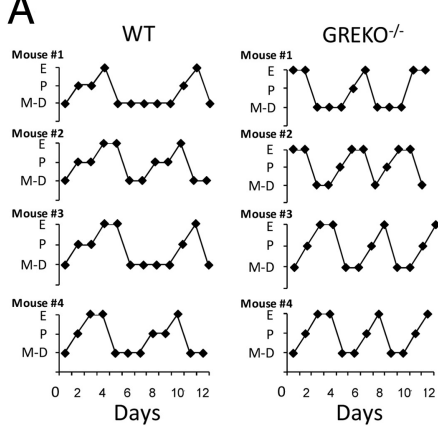

C

$B$
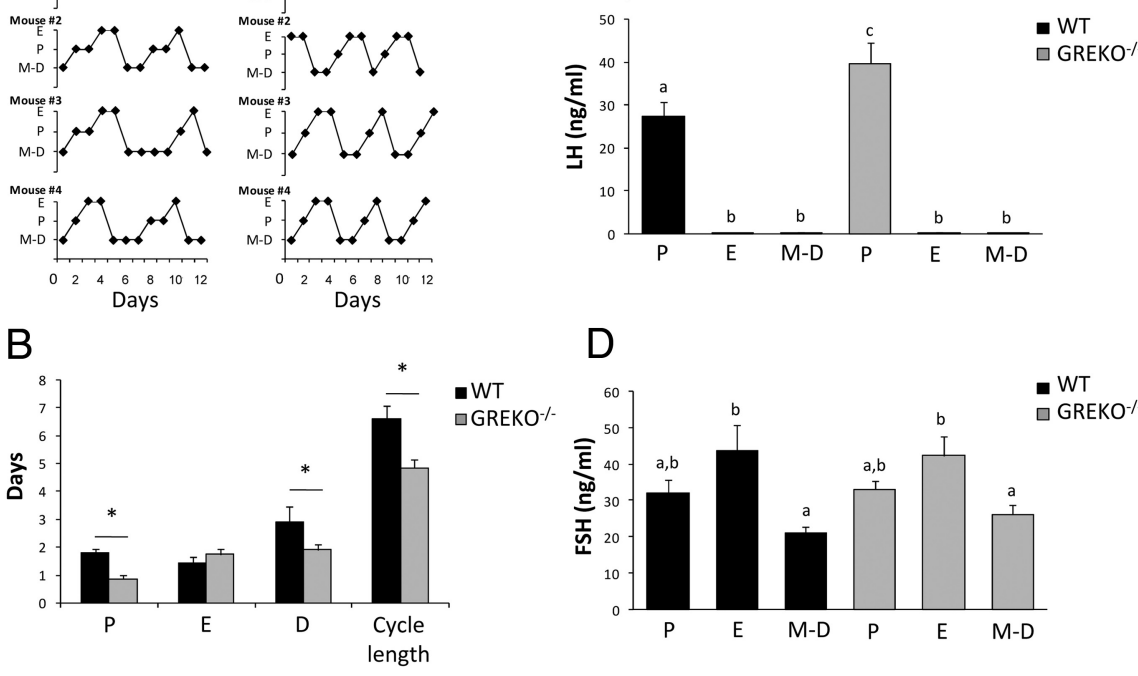

D

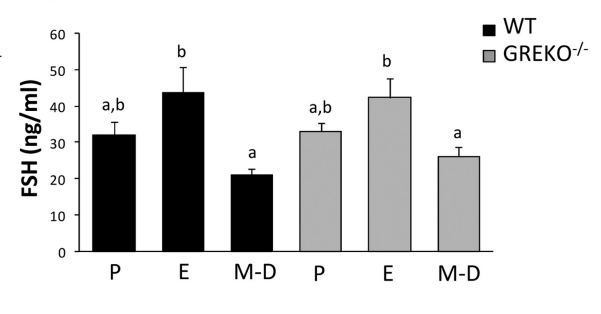

Figure 5. GREKO ${ }^{-1-}$ mice have shortened estrous cycles. $A$, Graphic representation of the respective estrous cyclicity in WT and GREKO ${ }^{-1-}$ mice. $\boldsymbol{B}$, Graphic representation of the means $\pm S E$ of the number of days in each stage of the estrous cycle and the total cycle length. Proestrus (P), estrus (E), and metestrus-diestrus (M-D) determined by vaginal cytology followed for $12 \mathrm{~d}(n=4)$. ${ }^{*} p \leq 0.05 . \boldsymbol{C}, \boldsymbol{D}, \mathrm{LH}(\boldsymbol{C})$ and FSH serum $(\boldsymbol{D})$ levels during the estrous cycle. There is no statistical difference between groups with the same letters $(n=3-5, p \leq 0.05)$. 
Table 1. Estrous cycles in GREKO ${ }^{-1-}$ female mice

\begin{tabular}{lrr}
\hline & $\begin{array}{l}\text { WT } \\
(n=4)\end{array}$ & \multicolumn{1}{c}{$\begin{array}{l}\text { GREKO } \\
(n=5)\end{array}$} \\
\hline Frequency of estrous cycles & $\begin{array}{r}1.83 \pm 0.12 \\
\text { Mean number of days required for one estrous cycle }\end{array}$ & $\begin{array}{r}2.64 \pm 0.6 \pm 0.46 \\
\text { Adult female mice were examined for estrous cyclicity by daily vaginal smear over a period of } 12 \mathrm{~d}(n=4-5) .\end{array}$ \\
\hline *Indicates statistically significant differences between groups $(p \leq 0.05)$.
\end{tabular}

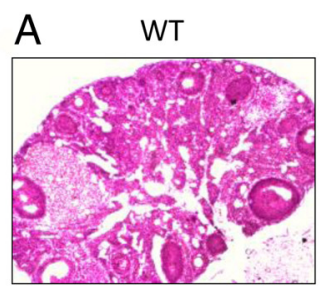

C

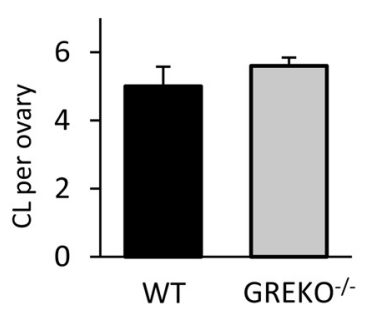

D

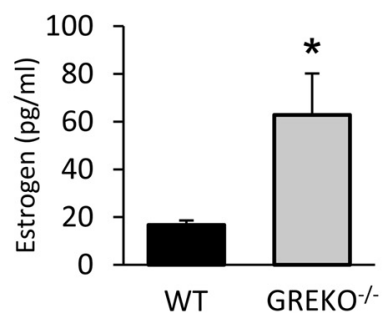

B GREKO

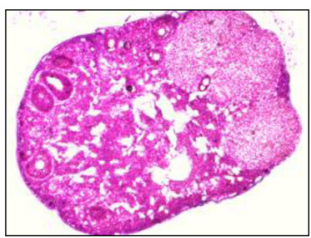

$\mathrm{E}$

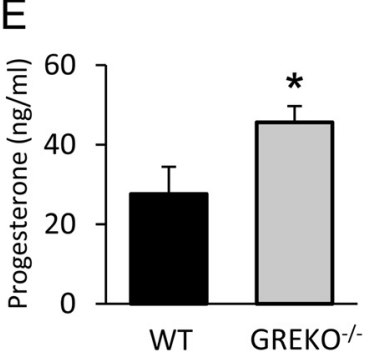

Figure 6. $\quad \boldsymbol{A}, \boldsymbol{B}, \mathrm{H} \& \mathrm{E}-$-stained ovary sections of WT $(\boldsymbol{A})$ and $\mathrm{GREKO}^{-/-}(\boldsymbol{B})$ mice (examined in diestrus phase). Ovarian sections from GREKO ${ }^{-1-}$ mice displayed, in general, less organization than the WT ovaries. $\boldsymbol{C}$, An increase in interstitial space, with the same variety of different follicle types and the same average number of corpora lutea $(C L)$, was observed $(n=3-5) \cdot \boldsymbol{D}, \boldsymbol{E}, \mathrm{E}_{2}(\boldsymbol{D})$ and progesterone $(\boldsymbol{E})$ serum levels in WT and GREKO ${ }^{-1-}$ mice $(n=4-9){ }^{*} p \leq 0.05$.

\section{Hypothalamic GnRH}

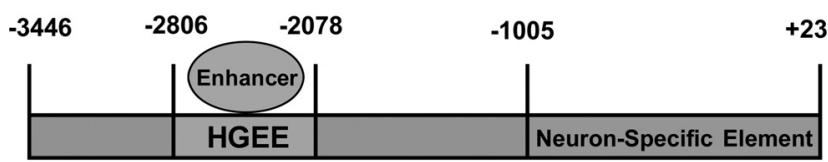

Hypothalamic GnRH E彑nhancer Element

\section{Ovarian GnRH}

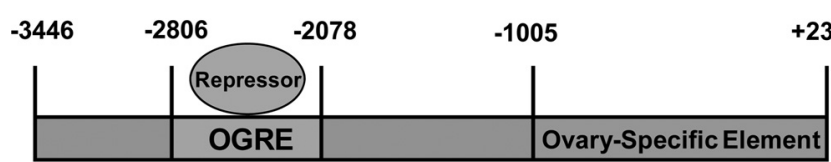

OVvarian $\underline{G} n R H \underline{R} e p r e s s o r$ Element

Figure 7. Model representing our understanding of tissue-specific expression of neuronal and ovarian GnRH. The GnRH regulatory element, GRE, contained between -2806 and -2078 bp on the $\mathrm{mGnRH}$ promoter, supporting the presence of a hypothalamic $\mathrm{GnRH}$ enhancer element and an ovarian $\mathrm{GnRH}$ repressor element.

with a delay in pubertal onset and shortened estrous cycles. Although the hypothalamus and pituitary are the principal source and target sites, respectively, for GnRH, several reports have suggested an extra-hypothalamic origin of $\mathrm{GnRH}$ and its receptor (Ramakrishnappa et al., 2005; Kim et al., 2007). However, the control of cell-specific expression and differential regulation of this decapeptide is not clear.
In vitro models using the GT1-7 cell line have shown that sequential deletions of the $\mathrm{rGnRH}$ gene promoter identified a neuron-specific enhancer, located between -1863 and -1571 $\mathrm{bp}$, which was found to be critical for the expression of the rGnRH gene (Nelson et al., 2000; Kelley et al., 2002; Givens et al., 2004). This region of the rat promoter shares $90 \%$ homology to the region of the $\mathrm{mGnRH}$ promoter located between -2384 and $-2081 \mathrm{bp}$, which was also shown to act as an enhancer of hypothalamic $\mathrm{mGnRH}$ expression in other studies performed in GT1-7 cells (Nelson et al., 2000; Kelley et al., 2002; Givens et al., 2004).

Because in vitro studies are unlikely to reflect the elaborate intricacy of $\mathrm{GnRH}$ gene regulation, in vivo models have been developed. Utilizing transgenic mice containing different $\mathrm{GnRH}$ promoter deletion constructs fused to a LUC reporter gene, our laboratory was able to target specific sequences in the $\mathrm{mGnRH}$ gene that behave as cell-specific enhancers or repressors (Kim et al., 2002, 2007). Most notably, there were relatively high levels of hypothalamic LUC expression and minimal ovarian LUC activity in the -3446 mGnRH-LUC mice, while the -2078 mGnRH-LUC mice showed less GnRH expression in the hypothalamus and higher levels of LUC activity in the ovaries (Kim et al., 2002), suggesting that the region between -3446 and -2078 of the $\mathrm{mGnRH}$ gene acts as a hypothalamic enhancer element and also as an ovarian repressor element (Kim et al., 2002).

To further define this region, in the current study we have constructed the additional $-2806 \mathrm{mGnRH}$-LUC mice. We again noted hypothalamic LUC expression and minimal ovarian LUC activity in these mice, similar to that previously reported in $-3446 \mathrm{mGnRH}-\mathrm{LUC}$ mice. These results highlight critical enhancer sequences for the in vivo expression of hypothalamic $\mathrm{mGnRH}$ that are located between -2806 and -2078 bp of the $\mathrm{mGnRH}$ promoter, which also contains repressor sequences for $\mathrm{mGnRH}$ expression in ovary, hence now referred to as the GRE.

Since expression of a transgene may affect cellular function, we sought to further characterize the GRE of the $\mathrm{mGnRH}$ gene by constructing a knock-out mouse model bearing a deletion of the $\mathrm{GnRH}$ enhancer/repressor located between -2806 and -2078 bp $\left(\mathrm{GREKO}^{-1-}\right)$. In the GREKO ${ }^{-1-}$ mice, we demonstrated markedly lower mGnRH mRNA levels in the hypothalamus of both female and male mice with a simultaneous rise in ovarian $\mathrm{mGnRH}$ mRNA levels and no changes in testicular mGnRH expression. This suggests a sexual dimorphism in GnRH expression in $\mathrm{GREKO}^{-1-}$ mice. These findings strongly corroborate the previous studies using transgenic LUC mice. In addition, changes in GnRH mRNA levels observed in the hypothalamus and ovary of WT mice during the estrous cycle were not observed in the $\mathrm{GREKO}^{-1-}$ model, suggesting that this element is required for normal GnRH expression and also for modulating regulatory cycling cues.

To determine whether the promoter enhancer affected GnRH neuron number or anatomic location, we performed immunohistochemistry for GnRH. The promoter deletion had no effect 
on the number, morphologic appearance, or distribution of GnRH neurons in the hypothalamus of adult $\mathrm{GREKO}^{-1-}$ mice. In contrast, deletion of this GRE revealed a robust fivefold increase in GnRH mRNA expression in the ovaries of GREKO ${ }^{-1-}$ mice. Furthermore, immunohistochemical analysis highlighted $\mathrm{GnRH}$ protein expression in the ovary, providing additional evidence that this region of the promoter behaves as a repressor of $\mathrm{GnRH}$ expression in the ovary. There is historical and now increasing evidence that GnRH is produced in the ovary and modulates ovarian function, regulating steroidogenesis, follicular development, and corpus luteum function (Knecht et al., 1985; Peng et al., 1994; Väänänen et al., 1997; Kang et al., 2001). GnRH mRNA has been detected in theca, granulosa, and ovarian surface epithelial cells in human and rodent ovaries (Peng et al., 1994; Kogo et al., 1999; Kang et al., 2000). GnRH peptide has also been demonstrated in human preovulatory follicles and mature corpora lutea (Choi et al., 2006). This model is unique in that the repressor element has been removed from the ovarian $\mathrm{GnRH}$ gene, allowing for chronically elevated GnRH in the ovary with decreased regulation by central factors and pathways. Based on the information presented above and to further explore the functional relevance of the increased $\mathrm{GnRH}$ expression in $\mathrm{GREKO}^{-/-}$ovaries, we evaluated serum $\mathrm{E}_{2}$ and progesterone levels as markers of ovarian function. Our studies showed an increase in gonadal steroid levels, suggesting that impaired hypothalamus-pituitary-gonadal axis feedback regulation in this knock-out mouse model may account for the cyclic changes. Ovarian steroids are essential for the modulation of pituitary responsiveness to $\mathrm{GnRH}$ and $\mathrm{GnRH}$ self-priming (Roa et al., 2008). Thus, it is tempting to propose that the rise in estradiol levels during proestrus, in the presence of activated progesterone receptors, evokes a state of hyper-responsiveness that contributes to the generation of the higher preovulatory surge of gonadotropins in the GREKO ${ }^{-1-}$ mice. However, we cannot discount the possible functional role of elevated ovarian $\mathrm{GnRH}$ in the $\mathrm{GREKO}^{-1-}$ mice on cyclicity.

The significant delay in pubertal onset and time to first delivery in the GREKO ${ }^{-1-}$ mice directly implicate the GRE in mediating these critical physiologic events. Interestingly, once puberty was achieved, there was no difference in the timing of the first estrous cycle between these groups. This would then imply that the delay in pubertal onset is in fact the cause of the delay in the time of first delivery. The mechanism behind this delay in puberty is not entirely clear. Gamble et al. (2005) and Herbison et al. (2008) have shown a nonsignificant delay in puberty in mice with as few as $66 \pm 15 \mathrm{GnRH}$ neurons (12\% of WT mice) in a mutant mouse line. Interestingly, they also did not manifest a difference in the onset of first estrus, suggesting that perhaps once a threshold of GnRH expression is achieved, normal development follows. However, the mechanism by which neuronal number mediated the timing of pubertal onset was unclear. The result of our studies shows that GRE of the GnRH promoter plays a role in mediating GnRH expression associated with pubertal onset. This provides further evidence that it is not merely a reduction in the number of $\mathrm{GnRH}$ neurons that causes the pubertal delay, but rather an intrinsic, genetic, localized regulatory defect.

In an attempt to evaluate further the hormonal milieu in our model, we determined the pattern of estrous cycles of these mice. We observed a decrease in the time spent in both proestrus and metestrus/diestrus in the knock-out mice. This led to an overall decreased cycle length in the GREKO ${ }^{-1-}$ mice. The elevated ovarian $\mathrm{GnRH}$ levels, high serum levels of $\mathrm{E}_{2}$ and progesterone, and the serum LH levels in proestrus may con- tribute to the shortening of phases of the estrous cycle in the $\mathrm{GREKO}^{-1-}$ mice.

The GREKO ${ }^{-1-}$ females exhibited normal fertility. They had similar numbers of litters and sizes of litters compared to the control group; however, they exhibited an irregular interval between deliveries $(18-42 \mathrm{~d})$. This may be due to the decreased time that the knock-out females spend in proestrus, thus making exact timing of conception more difficult. In addition, by counting CL in completely dissected ovaries from adult females we estimated the number of eggs shed from the ovaries (an estimate for the ovulation rate), and, as expected, no differences between these groups were observed. Furthermore, serum FSH levels had a similar pattern when $\mathrm{GREKO}^{-1-}$ were compared with WT mice.

Our model directly links the GRE to tissue-specific expression of $\mathrm{GnRH}$ and the acceleration of the estrous cycle. It then follows that the GRE region must normally bind regulatory proteins, and that without this element $\mathrm{GnRH}$ is expressed in a different pattern, which in turn delays puberty and shortens the estrous cycle. The factors that may regulate expression have been suggested in several studies. Oct-1 (Clark and Mellon, 1995) and GATA-4 (Lawson et al., 1996, 1998) were identified as important transcription factors that bind to the neuron-specific enhancer and regulate $\mathrm{GnRH}$ expression in vitro. Mutation of a critical Oct-1 binding site in the $\mathrm{rGnRH}$ enhancer element resulted in a dramatic decrease in GnRH pulsatility in GT1-7 cells (VazquezMartinez et al., 2002; Leclerc and Boockfor, 2005). These results forge an important link between $\mathrm{GnRH}$ expression and pulsatile $\mathrm{GnRH}$ secretion. Analysis of the corresponding mouse gene sequences, between -2384 and -2081 bp reveals similarities in presumed transcription factor recognition sites. These studies documented the presence of a functional Oct-1 binding site in the $\mathrm{mGnRH}$ gene promoter region between -2259 and -2252 bp (Chandran and DeFranco, 1999). Clearly, additional in vivo studies are needed to determine whether Oct-1 has a critical role in the differential regulation of hypothalamic and ovarian GnRH expression.

In conclusion, our data suggest a model of tissue-specific expression of hypothalamic and ovarian $\mathrm{GnRH}$ as depicted in Figure 7. Our results clearly demonstrate that the DNA sequence contained between -2806 and -2078 bp of the mGnRH promoter is sufficient to direct $\mathrm{mGnRH}$ gene expression to both the hypothalamus and ovary. Most importantly, for the first time we demonstrate that the enhancer/repressor element of the $\mathrm{GnRH}$ promoter mediates the timing of pubertal onset and normal estrous cycling. This work forms the foundation to define the proteins important for puberty and estrous cycling in mammals mediated by the GnRH regulatory element.

\section{References}

Bunting M, Bernstein KE, Greer JM, Capecchi MR, Thomas KR (1999) Targeting genes for self-excision in the germ line. Genes Dev 13:1524-1528.

Bustin SA, Benes V, Nolan T, Pfaffl MW (2005) Quantitative real-time RTPCR—a perspective. J Mol Endocrinol 34:597-601.

Chandran UR, DeFranco DB (1999) Regulation of gonadotropin-releasing hormone gene transcription. Behav Brain Res 105:29-36.

Choi JH, Gilks CB, Auersperg N, Leung PC (2006) Immunolocalization of gonadotropin-releasing hormone (GnRH)-I, GnRH-II, and type I GnRH receptor during follicular development in the human ovary. J Clin Endocrinol Metab 91:4562-4570.

Clark ME, Mellon PL (1995) The POU homeodomain transcription factor Oct-1 is essential for activity of the gonadotropin-releasing hormone neuron-specific enhancer. Mol Cell Biol 15:6169-6177.

Eraly SA, Mellon PL (1995) Regulation of gonadotropin-releasing hormone 
transcription by protein kinase $\mathrm{C}$ is mediated by evolutionarily conserved promoter-proximal elements. Mol Endocrinol 9:848-859.

Gamble JA, Karunadasa DK, Pape JR, Skynner MJ, Todman MG, Bicknell RJ, Allen JP, Herbison AE (2005) Disruption of ephrin signaling associates with disordered axophilic migration of the gonadotropin-releasing hormone neurons. J Neurosci 25:3142-3150.

Givens ML, Kurotani R, Rave-Harel N, Miller NL, Mellon PL (2004) Phylogenetic footprinting reveals evolutionarily conserved regions of the gonadotropin-releasing hormone gene that enhance cell-specific expression. Mol Endocrinol 18:2950-2966.

Herbison AE, Porteous R, Pape JR, Mora JM, Hurst PR (2008) Gonadotropin-releasing hormone neuron requirements for puberty, ovulation, and fertility. Endocrinology 149:597-604.

Kang SK, Choi KC, Cheng KW, Nathwani PS, Auersperg N, Leung PC (2000) Role of gonadotropin-releasing hormone as an autocrine growth factor in human ovarian surface epithelium. Endocrinology 141:72-80.

Kang SK, Tai CJ, Nathwani PS, Leung PC (2001) Differential regulation of two forms of gonadotropin-releasing hormone messenger ribonucleic acid in human granulosa-luteal cells. Endocrinology 142:182-192.

Kelley CG, Givens ML, Rave-Harel N, Nelson SB, Anderson S, Mellon PL (2002) Neuron-restricted expression of the rat gonadotropin-releasing hormone gene is conferred by a cell-specific protein complex that binds repeated CAATT elements. Mol Endocrinol 16:2413-2425.

Kim HH, Wolfe A, Smith GR, Tobet SA, Radovick S (2002) Promoter sequences targeting tissue-specific gene expression of hypothalamic and ovarian gonadotropin-releasing hormone in vivo. J Biol Chem 277:5194-5202.

Kim HH, Mui KL, Nikrodhanond AA, Tamayo NC (2007) Regulation of gonadotropin-releasing hormone in nonhypothalamic tissues. Semin Reprod Med 25:326-336.

Knecht M, Ranta T, Feng P, Shinohara O, Catt KJ (1985) Gonadotropinreleasing hormone as a modulator of ovarian function. J Steroid Biochem 23:771-778.

Kogo H, Fujimoto T, Park MK, Mori T (1999) Gonadotropin-releasing hormone receptor mRNA expression in the ovaries of neonatal and adult rats. Cells Tissues Organs 164:14-22.

Langford KG, Shai SY, Howard TE, Kovac MJ, Overbeek PA, Bernstein KE (1991) Transgenic mice demonstrate a testis-specific promoter for angiotensin-converting enzyme. J Biol Chem 266:15559-15562.

Lawson MA, Whyte DB, Mellon PL (1996) GATA factors are essential for activity of the neuron-specific enhancer of the gonadotropin-releasing hormone gene. Mol Cell Biol 16:3596-3605.

Lawson MA, Buhain AR, Jovenal JC, Mellon PL (1998) Multiple factors interacting at the GATA sites of the gonadotropin-releasing hormone neuron-specific enhancer regulate gene expression. Mol Endocrinol 12:364-377.

Leclerc GM, Boockfor FR (2005) Identification of a novel OCT1 binding site that is necessary for the elaboration of pulses of rat $\mathrm{GnRH}$ promoter activity. Mol Cell Endocrinol 245:86-92.

Mellon PL, Windle JJ, Goldsmith PC, Padula CA, Roberts JL, Weiner RI (1990) Immortalization of hypothalamic GnRH neurons by genetically targeted tumorigenesis. Neuron 5:1-10.

Nelson JF, Felicio LS, Randall PK, Sims C, Finch CE (1982) A longitudinal study of estrous cyclicity in aging C57BL/6J mice: I. Cycle frequency, length and vaginal cytology. Biol Reprod 27:327-339.

Nelson SB, Lawson MA, Kelley CG, Mellon PL (2000) Neuron-specific expression of the rat gonadotropin-releasing hormone gene is conferred by interactions of a defined promoter element with the enhancer in GT1-7 cells. Mol Endocrinol 14:1509-1522.

Peng C, Fan NC, Ligier M, Väänänen J, Leung PC (1994) Expression and regulation of gonadotropin-releasing hormone $(\mathrm{GnRH})$ and $\mathrm{GnRH}$ receptor messenger ribonucleic acids in human granulosa-luteal cells. Endocrinology 135:1740-1746.

Radovick S, Wray S, Lee E, Nicols DK, Nakayama Y, Weintraub BD, Westphal H, Cutler GB Jr, Wondisford FE (1991) Migratory arrest of gonadotropin-releasing hormone neurons in transgenic mice. Proc Natl Acad Sci U S A 88:3402-3406.

Ramakrishnappa N, Rajamahendran R, Lin YM, Leung PC (2005) GnRH in non-hypothalamic reproductive tissues. Anim Reprod Sci 88:95-113.

Roa J, Aguilar E, Dieguez C, Pinilla L, Tena-Sempere M (2008) New frontiers in kisspeptin/GPR54 physiology as fundamental gatekeepers of reproductive function. Front Neuroendocrinol 29:48-69.

Singh SP, Wolfe A, Ng Y, DiVall SA, Buggs C, Levine JE, Wondisford FE, Radovick S (2009) Impaired estrogen feedback and infertility in female mice with pituitary-specific deletion of estrogen receptor alpha (ESR1). Biol Reprod 81:488-496.

Spanel-Borowski K, Schäfer I, Zimmermann S, Engel W, Adham IM (2001) Increase in final stages of follicular atresia and premature decay of corpora lutea in Insl3-deficient mice. Mol Reprod Dev 58:281-286.

Väänänen JE, Tong BL, Väänänen CM, Chan IH, Yuen BH, Leung PC (1997) Interaction of prostaglandin F2alpha and gonadotropin-releasing hormone on progesterone and estradiol production in human granulosaluteal cells. Biol Reprod 57:1346-1353.

Vazquez-Martinez R, Leclerc GM, Wierman ME, Boockfor FR (2002) Episodic activation of the rat $\mathrm{GnRH}$ promoter: role of the homeoprotein oct-1. Mol Endocrinol 16:2093-2100.

Whyte DB, Lawson MA, Belsham DD, Eraly SA, Bond CT, Adelman JP, Mellon PL (1995) A neuron-specific enhancer targets expression of the gonadotropin-releasing hormone gene to hypothalamic neurosecretory neurons. Mol Endocrinol 9:467-477.

Wolfe A, Ng Y, Divall SA, Singh SP, Radovick S (2008) Development of an immortalised, post-pubertal gonadotrophin-releasing hormone neuronal cell line. J Neuroendocrinol 20:1029-1037. 